\title{
Probing into Native and Nonnative Students' Mental Lexicon: a Case of Word Association Comparison
}

\section{Спроби аналізу ментального лексикону носіїв та не носіїв мови: випадок асоціативного порівняння слова}

\author{
Afrooz Marzban \\ Ph.D. candidate in TEFL \\ Department of English, Shiraz Branch, \\ Islamic Azad University, Shiraz, Iran
}

\author{
Афруз Маржан \\ аспірант \\ кафедра англійської мови, \\ Ширазький філіал, Ісламський \\ університет Азад, Шираз, Іран
}

Mohammad Sadegh Bagheri

Ph.D. in TEFL, Assistant rofessor

Department of English, Shiraz Branch, Islamic Azad University, Shiraz, Iran
Мохамед Садег Багері

кандидат наук з методики викладання англійської мови як іноземної, доцент

E-mail: bagheries@gmail.com 0000-0001-9771-113X

\section{Firooz Sadighi}

Ph.D. in TEFL, Professor Department of English, Shiraz Branch, Islamic Azad University, Shiraz, Iran

\section{Фіроз Задігі}

кандидат наук з методики викладання англійської мови

як іноземної, професор

E-mail: firoozsadighi@yahoo.com

Ehsan Rassaei

Ph.D. in TEFL, Associate Professor

Department of English, Shiraz Branch,

Islamic Azad University, Shiraz, Iran

\author{
Езан Рacei \\ кандидат наук з методики \\ викладання англійської мови \\ як іноземної, доцент
}

\section{E-mail: ehsanrassaei@yahoo.com 0000-0001-6477-9752}


Спроби аналізу ментального лексикону носїв та не носіїв мови...

Islamic Azad University, Shiraz branch,

Department of English, Language Teaching

$5^{\text {th }} \mathrm{km}$ of Sadra HWY, P.O. Box 5-71993 Shiraz, Iran

Original manuscript received November 25, 2018

Revised manuscript accepted February 02, 2019

\begin{abstract}
The present study compared British English speakers' (native) and Iranian EFL learners' (nonnative) mental lexicon structure focusing on how words are selected and used by the two groups. The types of word association links, syntagmatic and paradigmatic, more frequently applied by the two groups of the participants, were probed into. To this end, 40 native and 40 nonnative college students, both male and female, were compared as far as mental lexicon was concerned. Accordingly, through the Oxford Placement Test (OPT), the nonnative subjects were assigned to three ability levels; namely, high, mid and low. Next, the Word Association Test (WAT) was administered respectively to all native and nonnative participants. The comparison of the WAT results through a series of Chi-square tests and a test of Mann-Whitney indicated that the employed word association links varied among the native and nonnative participants. The findings revealed that the low and mid level nonnatives which comprised a majority of Iranian EFL learners employed the syntagmatic relation to a greater extent than the high level nonnatives. However, only one resemblance was observed between the natives and the high level nonnatives who frequently applied the paradigmatic link. Thus, it was concluded that the advanced Iranian learners performed in a similar way as that of the native English speakers; as a result, it was suggested that the improvement in the proficiency level could lead to a change in making mental links. The findings would contribute to the psychological concerns in language teaching and learning in most academic contexts of higher age ranges.
\end{abstract}

Key words: mental lexicon, word association, paradigmatic link, syntagmatic relation, mental links.

\title{
Introduction
}

According to Aitchison (2003), words are fascinating and we depend on them as part of our everyday life. As McCarthy (1990) puts it, vocabulary is of considerable importance to communicating in a foreign language which cannot happen in a meaningful way without sufficient words to express a wide variety of meanings. As such, vocabulary acquisition is a main concern for EFL learners, and it is a 
main focus of their interest and attention. Learning how to link between words is one of the most significant ways of learning vocabulary in foreign language acquisition, which is usually ignored and has not received the attention it is worthy of in Iran. By doing this comparative study, word association will be hopefully paid more attention.

Studies on first and second language word association, language organization and the related mechanisms that allow us to retrieve the words we know immediately and correctly, have been of interest to linguists and psycholinguists over the recent years. Psycholinguistic studies have shown that words are not stored in the mental lexicon as single independent items, but form clusters or webs with other related concepts so that words acquire their full meaning in reference to related terms (Aitchison, 1994, cited in Russ, 2010).

Focusing on how words are selected and used by both native English speakers and Iranian EFL learners, i.e. the strategies involved in finding the chosen words by them and the central role of mental lexicon in language processing constitute the main aims of this study. Thus, the significant steps taken in this study are looking for the existence of any differences or similarities between native and different levels of nonnative mental lexicon, i.e. the differences or similarities in the word association strategies (syntagmatic or paradigmatic) they may employ and the particular strategies that are applied more by the two groups.

\section{Literature Review \\ Mental Lexicon}

The mental lexicon is a metaphor used to describe how words might be stored in the mind and retrieved. Commonly cited metaphors include descriptions of the mental lexicon as a dictionary, a thesaurus, an encyclopedia, a library, a computer, a network, and a web (McCarthy, 1990). The mental lexicon is complex, far beyond our current level of understanding or ability to create a complete model based on measurable data: a metaphorical description is therefore limited in its representation and should be treated with caution (Wilks \& Meara, 2002; Coulthard et al., 2000). Nevertheless, metaphors can be devices for describing what is otherwise beyond comprehension, and, arguably, they have the potential to push our thinking and deepen our understanding. 
The mental lexicon is perceived to be multi-dimensional with underlying semantic organizing principles, indicated by word associations. It is affected by wide ranging variables which differ from one individual to the next, and change in both time and space (Carter, 1987). Research into bilinguals and second language acquisition has indicated similarities suggestive of an overlap between the L1 and L2 mental lexicon (Grabois, 1999; Coulthard et al., 2000; Swan, 1997; Carter, 1987). Aitchison (2003) points to evidence supporting 'a single integrated network' whilst conceding that the organization of the mental lexicon in bilingual and multilingual speakers requires further investigation.

According to Barrow (2011), when looking into the mental lexicon, considering links between a person's language knowledge and language usage are important (Aitchison, 1998); however, acquiring word meaning is a complex process (Henriksen, 1999). The mental lexicon determines how a word is written, pronounced, its part of speech and what a word means (Garnham, 1985). It has been described as a 'web of words' and a network which has a multidimensional complexity (Wilks \& Meara, 2002). A mental map, the same as the plan of the London Underground System, is a network which is actually much more complex (Aitchison, 2003). There is no guarantee that human minds work in a neat and economical fashion, as some words are not easy to retrieve, however, the lexicon is an intricate system and words can be found and selected quickly (Aitchison, 2003).

\section{Structural Similarities / Differences in the L1 and L2 Mental Lexicon}

According to Aitchison (2003), the mental lexicon is an internally joined system, however the analysis of these structural similarities or differences has been a controversial issue in Lexical research. It has been claimed that an L1 lexicon is structurally different from the L2 lexicon (Channell, 1990). Meara (1983) asserts that there are major differences between the structure of the L1 and L2 mental lexicon, since connections made by L2 speakers are less steady than native speakers, in addition phonetic links are often more common in L2 than L1 associates. However, according to Wolter (2001) although the L2 lexicon may be less developed as syntagmatic links are dominant, there are structural similarities between the L1 and L2 lexicon. However, this may not mean that the L2 lexicon is less structurally notable, as paradigmatic links may not play as crucial a role in the L2 lexicon than 
in the L1 lexicon (Wolter, 2001). It has also been recommended that being mostly phonetic, L2 responses require less lexical sophistication than paradigmatic or syntagmatic associates (Wolter, 2001).

\section{Word Association Types}

According to Peppard (2007), two main organizing principles of language that are focused by the majority of word association literature include: syntagmatic (chain) and paradigmatic (choice) associations. Syntagmatic relations are those that would be related by a phrase or syntactic structure. Paradigmatic associations, on the other hand, involve the other words that could replace the target word. These main associations in turn embrace certain smaller parts. The subdivisions of syntagmatic links include collocation, multi-word units and encyclopedic knowledge. The subgroups of paradigmatic links consist of coordination, hyponymy and synonymy. As Peppard (2007) suggested, in previous research native speakers tended to respond to word association stimuli paradigmatically while non- native speakers tended to respond syntagmatically (Coulthard et al., 2000; Meara, 1982). Word associations can only be based on their phonological or orthographic links besides the paradigmatic/syntagmatic distinction. Some responses, labeled encyclopaedic responses, are related to one's personal knowledge about the word. Finally another type of responses which are not so common and usually given by low-level language learners are referred to as clang responses.

\section{Word Association Tests}

The British psychologist, Sir Francis Galton first developed the word association test in the early nineteenth century. It was later refined by Wilhelm Wundt near the end of the nineteenth century. As Stevens (1994) suggests, it was originally used as a psychological tool to investigate the subconscious mind, and more recently applied by psycholinguists to look into the mental lexicon. Galton picked seventyfive words randomly, looked at them in turn, getting down the first two words that came to his head as a result right away. Regarding the consequences of Galton, Aitchison (2003: 24) wrote: «The records lay bare the foundations of a man's thoughts with curious distinctness and show his mental anatomy with more truth and vividness than he himself would possibly care to publish to the world».

Channell (in McCarthy, 1990: 35) suggests that «we should not necessarily assume that the mind organizes the lexicon of a second 
language in the same way as it does its first». As Piper and Leicester (1980) concluded, significant differences were found between beginner ESL students and native speakers however these differences decreased between advanced ESL learners and native speakers. According to Aitchison (2003), the most common relation between L1 speaker test responses is coordination, whereas collocation, superordination and synonymy also occur continually.

Soderman (1993) interestingly accounted for the shift in response type. As she indicated, this shift should be associated with the growth of single words in the lexicon of a native speaker or foreign language learner without considering their level of proficiency. It was suggested that the individual words being incorporated in the lexicon are influenced by lexical development which is a slow process. The data of the study seem to back this suggestion that a surprisingly large number of syntagmatic responses as well as a number of clang associates were produced by even the most advanced L2 learners.

\section{Research Questions}

1. Do native and different proficiency levels of nonnative subjects follow the same strategies (either syntagmatic or paradigmatic) when finding the words they want to use?

2 Are there any differences between the native and the high level (proficient) nonnative subjects in terms of making mental links?

\section{Method \\ Participants}

The participants who took part in the study were totally 110 adult native and non-native English students, both male and female, aged between 20 and 30. The natives cooperated from Metropolitan college in Birmingham, United Kingdom and the non-natives participated from Shamim Arghavan Language Institute in Shiraz, Iran. Some participants were excluded from the data analysis due to their uncategorized responses or careless coding. This brought the final number of participants to 80 subjects who were divided into two groups equal in number, i.e. 40 native speakers of English and 40 Iranian EFL learners.

\section{Instrumentation}

\section{Word Association Test (WAT)}

It is a test of personality and mental function in which the subject is required to respond to each of a series of words with the first word 
that comes to mind or with a word of a specified class of words as antonyms. WAT was first developed as a research instrument by Francis Galton, later refined by Wilhelm Wundt near the end of the nineteenth century and was subsequently developed by Carl Jung as a clinical diagnostic tool which usually consisted of a hundred stimulus words that were read out singly to a subject who was to answer as quickly as possible with the word that occurred to him/her (Stevens, 1994). The word association test used in this study was formulated based on Khazaeenezhad and Alibabaee's test (2013) which was in turn devised based on Wolter's test (2002). It consisted of 10 words as the prompts from the Edinburgh Associative Thesaurus (EAT, Kiss et al., 1973; available online at http://monkey.cis.rl.ac.uk/Eat/htdocs/eat.html) it was also a single response test. The researcher employed Cronbach's alpha to assess the go togetherness of the WAT items. The reliability of the WAT scale equalled .76, which was over 70 percent and thus a satisfactory value.

\section{Oxford Placement Test (OPT)}

The OPT developed by Oxford University Press, provides an easy, practical way of grading students and measures a student's general language ability so you can place him or her into the appropriate level class for a language course. This test was applied to place the nonnative participants into three ability groups of elementary, intermediate and high intermediate that were named as low, mid and high levels respectively.

\section{Data Collection Procedures}

The instruments, namely OPT and WAT were administered to the participants over a 2-week period. Participants were given 30 minutes to do the OPT but the WAT was not timed. This was considered by the researcher because it was decided that timing responses could create feelings of anxiety, and would contradict ethical considerations. The OPT, which was only administered to the nonnative participants, was employed to divide them into three ability groups. Out of 40 non-natives, 12 Students were ranked as «elementary», 15 as «intermediate» and 13 as «high intermediate» in terms of proficiency. They were named as low, mid and high levels respectively. Then the word association test (WAT) was administered to all native and different levels of nonnative subjects. It consisted of a list of ten stimulus words that was given to each participant individually. Students were encouraged to fill in each blank with the first word that they could think of when they read the word. 
There were no right or wrong answers. Responses were then decided on and categorized as syntagmatic and paradigmatic relations (called word association strategies in the present study) by the researcher with the aid of Dr. Firooz Saddighi as a psycholinguistics consultant. To ensure reliability, this procedure was repeated in exactly the same way with each of the 80 native and nonnative participants.

\section{Data Analysis Procedures}

The statistics were processed through SPSS version 23.0. To investigate and compare the performance of the participants on WAT and to analyze the data, and since WAT was a categorical scale, the Chisquare was employed and calculated as a proper inferential statistics to see if the comparison of the abundance of data was allowed. Then, due to the small number of the participants, the non-parametric test of MannWhitney was employed as another statistical method to liken the performance of the subjects on WAT.

\section{Findings}

First of all the normality of data distribution was checked through the Kolmogorov-Smirnove test. The value was satisfactory (.201) thus both parametric and non-parametric tests could be applied. As a result, in order to answer the first question, the parametric test of Chi-square was utilized. In this section, different levels of the nonnative group were compared to find out about what strategies they tended to employ when finding the words they wanted to use. So, as illustrated in Table 1, the Chisquare was calculated.

Table 1. Chi-square test results for the frequency of the responses to WAT in high, mid and low levels

Crosstabs

\begin{tabular}{llllcrr}
\hline \hline & \multicolumn{4}{c}{ Case Processing Summary } \\
& \multicolumn{2}{c}{ Cases } \\
& \multicolumn{2}{c}{ Valid } & \multicolumn{2}{c}{ Missing } & \multicolumn{2}{l}{ Total } \\
\cline { 2 - 8 } & $\mathrm{N}$ & Percent & $\mathrm{N}$ & Percent & $\mathrm{N}$ & Percent \\
\hline WAT * LEVEL & 40 & $100.0 \%$ & 0 & $0.0 \%$ & 40 & $100.0 \%$ \\
\hline
\end{tabular}


Probing into Native and Nonnative Students' Mental Lexicon...

\begin{tabular}{lcccccc}
\hline \multicolumn{7}{c}{ WAT * LEVEL Crosstabulation } \\
\hline \multirow{2}{*}{ WAT } & \multicolumn{5}{c}{ LEVEL } \\
& \multirow{2}{*}{1.00} & High & mid & low & Total \\
\cline { 3 - 7 } & & Count & 10 & 4 & 3 & 17 \\
\cline { 2 - 7 } & \multirow{2}{*}{2.00} & Count & 3 & 11 & 9 & $42.5 \%$ \\
\cline { 3 - 7 } & & $\%$ of Total & $7.5 \%$ & $27.5 \%$ & $22.5 \%$ & $57.5 \%$ \\
\hline \multirow{2}{*}{ Total } & Count & 13 & 15 & 12 & 40 \\
\cline { 3 - 7 } & & $\%$ of Total & $32.5 \%$ & $37.5 \%$ & $30.0 \%$ & $100.0 \%$ \\
\hline
\end{tabular}

\begin{tabular}{lccc}
\hline \multicolumn{3}{c}{ Chi-Square Tests } & \\
\hline & Value & df & $\begin{array}{c}\text { Asymptotic Significance } \\
\text { (2-sided) }\end{array}$ \\
\hline Pearson Chi-Square & $9.346 \mathrm{a}$ & 2 & .009 \\
\hline Likelihood Ratio & 9.610 & 2 & .008 \\
\hline Linear-by-Linear Association & 6.906 & 1 & .009 \\
\hline N of Valid Cases & 40 & & \\
\hline
\end{tabular}

a. 0 cells $(0.0 \%)$ have expected count less than 5 . The minimum expected count is 5.10

As illustrated in Table 1, the expected frequencies of no cells were less than 5. And the P-value was. 009 which is less than.05, so there was a difference in the performance of the three nonnative levels on WAT i.e., the low and mid results were relatively similar. This implies that low and mid levels had a greater tendency towards syntagmatic relation, while the high level tendency was greater towards paradigmatic relation.

After different levels of the nonnative group were analyzed and compared separately, it came to the native group whose employed strategies were investigated as well. In this section, a comparison was made between the nonnative group as a whole and the native group in order to find out how both groups, especially the native group, made mental links between the English words they have learnt. To this end, as Table 2 shows, a Chi-square was calculated to present the frequency of the responses to the WAT.

As depicted in Table 2, there was a difference in the performance of native and nonnative group on WAT because the expected frequencies of no cells were less than 5 and the P-value was.003 which was less 
Спроби аналізу ментального лексикону носїв та не носіїв мови...

than .05. Thus, the result approved the fact that the native group was mostly into employing the paradigmatic relation compared with the nonnative group that was more interested in using the syntagmatic relation.

Table 2. Chi-square test results for the frequency of the responses to WAT in the nonnatives \& natives

Crosstabs

\section{Case Processing Summary}

Cases

\begin{tabular}{lcccccr} 
& \multicolumn{2}{c}{ Valid } & \multicolumn{2}{c}{ Missing } & \multicolumn{2}{c}{ Total } \\
\cline { 2 - 7 } & $\mathrm{N}$ & Percent & $\mathrm{N}$ & Percent & $\mathrm{N}$ & Percent \\
\hline WAT * Country & 80 & $100.0 \%$ & 0 & $0.0 \%$ & 80 & $100.0 \%$ \\
\hline
\end{tabular}

\section{WAT* Country Crosstabulation}

\begin{tabular}{|c|c|c|c|c|c|}
\hline & & & \multicolumn{3}{|c|}{ Country } \\
\hline & & & non-native & native & Total \\
\hline \multirow[t]{4}{*}{ WAT } & 1.00 & Count & 17 & 30 & 47 \\
\hline & & $\%$ of Total & $21.3 \%$ & $37.5 \%$ & $58.8 \%$ \\
\hline & 2.00 & Count & 23 & 10 & 33 \\
\hline & & $\%$ of Total & $28.8 \%$ & $12.5 \%$ & $41.3 \%$ \\
\hline \multirow[t]{2}{*}{ Total } & & Count & 40 & 40 & 80 \\
\hline & & $\%$ of Total & $50.0 \%$ & $50.0 \%$ & $100.0 \%$ \\
\hline
\end{tabular}

\begin{tabular}{lccccc}
\hline \multicolumn{7}{c}{ Chi-Square Tests } \\
\hline & Value & df & $\begin{array}{c}\text { Asymptotic } \\
\text { Significance } \\
(2 \text {-sided })\end{array}$ & $\begin{array}{c}\text { Exact Sig. } \\
(2-\text {-sided })\end{array}$ & $\begin{array}{r}\text { Exact Sig. } \\
\text { (1-sided) }\end{array}$ \\
\hline Pearson Chi-Square & $8.717 \mathrm{a}$ & 1 & .003 & & \\
\hline Continuity Correctionb & 7.427 & 1 & .006 & .003 \\
\hline Likelihood Ratio & 8.906 & 1 & .003 & .006 \\
\hline Fisher's Exact Test & & & & \\
\hline Linear-by-Linear Association & 8.608 & 1 & .003 & \\
\hline N of Valid Cases & 80 & & & \\
\hline
\end{tabular}
a 0 cells $(0.0 \%)$ have expected count less than 5 . The minimum expected count is 16.50 .
b. Computed only for a $2 \times 2$ table 
To answer research question two, a comparison was made between the native and the high level nonnative subjects to find out about their generally employed word association links. The main reason of making such a comparison was that, the native group and the high level nonnative subjects were assumed to gain a similar level of proficiency in English so they were regarded as proper comparable subjects. To investigate the performance of these two groups on the scale of WAT, a series of descriptive statistics followed by the related inferential statistics (Mann-Whitney test) were conducted. The descriptive statistics for the performance of the native and the high level nonnative groups on WAT are presented in Table 3.

Table 3. Descriptive statistics for the high level \& natives' performance on WAT

\begin{tabular}{|c|c|c|c|c|c|}
\hline \multicolumn{6}{|c|}{ Case Processing Summary } \\
\hline & \multicolumn{5}{|c|}{ Cases } \\
\hline & \multicolumn{2}{|c|}{ Valid } & Missing & \multicolumn{2}{|c|}{ Total } \\
\hline & $\mathrm{N}$ & Percent & Percent & $\mathrm{N}$ & Percent \\
\hline country *WATTest & 53 & $100.0 \%$ & $.0 \%$ & 53 & $100.0 \%$ \\
\hline \multicolumn{6}{|c|}{ country * WATTest Crosstabulation } \\
\hline \multicolumn{6}{|l|}{ Count } \\
\hline & & & \multicolumn{2}{|c|}{ WATTest } & \\
\hline & & & paradigmatic & syntamatic & Total \\
\hline \multirow[t]{3}{*}{ Country } & & non-native high & 10 & 3 & 13 \\
\hline & & native & 30 & 10 & 40 \\
\hline & Total & & 40 & 13 & 53 \\
\hline
\end{tabular}

Table 3 depicts the sample dispersion and as it is illustrated, the sample contained no missing data and the paradigmatic relation was employed by more members of both natives and the high level nonnatives. Next, to make sure if there was a significant difference between the two groups, and due to the small number of the sample, the nonparametric test of Mann-Whitney was run. The results are reported in Table 4.

As Table 4 depicts, the P-value was .89 which is more than .05 , so no significant difference was observed between the two groups. 
Спроби аналізу ментального лексикону носїв та не носіїв мови...

Table 4. Difference between the natives and the high level nonnatives' performance on WAT

\begin{tabular}{lllcc}
\multicolumn{5}{c}{ Mann-Whitney Test } \\
\hline \multirow{3}{*}{ Ranks } \\
\hline \multirow{3}{*}{ country } & N & Mean Rank & Sum of Ranks \\
\cline { 2 - 5 } & non-native high & 13 & 26.62 & 346.00 \\
& native & 40 & 27.13 & 1085.00 \\
& Total & 53 & & \\
\hline
\end{tabular}

\begin{tabular}{lc}
\hline & Test Statisticsa \\
\hline & \\
Mann-Whitney U & WATTest \\
Wilcoxon W & 255.000 \\
Z & 346.000 \\
Asymp. Sig. (2-tailed) & -.139 \\
\hline
\end{tabular}

a. Grouping Variable: country

\section{Discussion}

To answer the first question, the frequently applied links by the two groups of the subjects were investigated and compared. As results indicated, the strategies or relations (syntagmatic/paradigmatic) varied among the native and nonnative participants. The findings of this study provided empirical backing for the differences between the L1 and L2 mental lexicon. The results were commensurate with the original theories of mental lexicon. According to Channell (1990), an L1 lexicon is structurally different from the L2 lexicon and as Meara (1983: 7) asserts, «there are major differences between the structure of the L1 and L2 mental lexicon since connections made by L2 speakers are less steady than native speakers. In addition, phonetic links are often more common in L2 than L1 associates.»

The findings were commensurate with that of Channell (in McCarthy, 1990) who asserted that mind shouldn't be necessarily assumed to organize the lexicon of a second language in the same way as it does its first. The results supported Wolter's (2001) assertion that although the L2 lexicon may be less developed as syntagmatic links are dominant, there are structural similarities between the L1 and 
L2 lexicon. However, this may not mean that the L2 lexicon is less structurally notable, as paradigmatic links may not play as crucial a role in the L2 lexicon as in the L1 lexicon. The findings of the present study confirmed those of the previous studies. Research into bilinguals and second language acquisition has indicated similarities suggestive of an overlap between the L1 and L2 mental lexicon (Grabois, 1999; Coulthard et al., 2000; Swan, 1997; Carter, 1987). Aitchison (2003) points to evidence supporting 'a single integrated network'. Finally, the results echoed those achieved by Coulthard et al., (2000) and Meara (1982) who revealed a tendency for native speakers to respond to word association stimuli paradigmatically and for nonnative speakers to respond syntagmatically. The results also supported that of Aitchison (2003) who observed that coordination (paradicmatic) link was the most common native-speaker word-association answers.

To answer the second research question, a comparison was made between the native and the high level nonnative subjects to find out their mostly employed word association links. The results indicated that there were no significant differences between the two groups regarding the applied word association strategies. The findings were in agreement with that of Piper and Leicester (1980) who found no differences between advanced ESL learners and native speakers, although differences increased between beginner ESL students and native speakers. On the other hand, the results contradicted Soderman's (1993) who suggested that even the most advanced L2 learners produced a surprisingly large number of syntagmatic responses as well as a number of clang associates.

\section{Conclusion}

The mental lexicon structure was proved to be different among the native English speakers and the three levels of Iranian EFL learners (nonnatives) as they didn't employ the same word association links. It was concluded that the natives commonly employed the paradigmatic association link. However, the Iranian low and mid levels generally employed the syntagmatic association link while the Iranian high level frequently employed the paradigmatic link. Therefore, it can be suggested that a majority of learners in an EFL context like Iran apply 
the syntagmatic link more frequently. Also, it can be implied that as the proficiency level improves, a shift would occur in making mental links and that the advanced Iranian learners would act the same as the natives, whereas, less proficient nonnatives would perform much more differently from the natives regarding making mental relations which in turn affect their learning style.

Thus, considering the similarity between the native and the high level nonnative subjects in terms of making mental links, it can also be concluded that the participants may perform in the same way concerning the residue of the association rations, namely the phonological link which wasn't discussed and included in the present study, so further research is required for yielding comprehensive results.

This study is different from previous research in the following ways. First, in the present work, unlike the previous research, word association links employed by both native and nonnative participants were investigated, i.e. the tendency of both native and nonnative students to respond to word association stimuli either paradigmatically or syntagmatically were examined. Next, the mental lexicon of native speakers of English and EFL learners were compared and conclusions brought forth findings which could explain the similarities or differences between the native and nonnative mental lexicon. And last but not least, in order to give a more holistic view of the lexicon, various testing measures have been presented to test word association and depth of word knowledge.

\section{Pedagogical Implications for the Research Findings}

This piece of research found that students employ different association strategies, finding the words they want to use and that they make different mental links between the English words they have learnt. Thus, first of all the findings of the present study contribute to the EFL or ESL learners. Because, as it can be inferred, being simply aware of their preferred or frequently employed association strategies, students may try to remember most of the previously learnt words easily and even on the basis of this knowledge they attempt to learn further words. Hence, studying the subconscious mind and exploring the mental lexicon of the learners may positively affect the learning style of the learners.

The results could also come in handy to English teachers. Being aware of the students' mental lexicon structure and knowing about their preferred association links, teachers may conduct a more suitable 
technique in teaching vocabulary. So, teachers are recommended to take such issues into account.

\section{References}

Aitchison, J. (1994). Words in the mind (2nd Ed.). Oxford: Blackwell Publishing. Aitchison, J. (1998). The articulate mammal: An introduction to psycholinguistics (4th Ed.). Oxon: Routledge Publishing.

Aitchison, J. (2003). Words in the mind (3rd Ed.). Oxford: Blackwell Publishing.

Barrow, S. (2011). First and second language word association. A study of how native English speakers and ESL learners make mental links between English words they have learnt. Unpublished masters thesis, University of Birmingham, Birmingham.

Carter, R. (1987). Vocabulary applied linguistics and perspectives. London: Routledge. Channell, J. (1990). Precise and vague quantities in academic writing. In W. Nash (Ed.), The writing scholar: Studies in the language and conventions of academic discourse. Newbury Park, CA: Sage Publications.

Coulthard, M., Knowles, M., Moon, R., \& Deignan, A. (2000). Lexis (2nd Ed.). Birmingham: The center for English language studies, University of Birmingham. Garnham, A. (1985). Psycholinguistics: Central topics. (1st Ed.). Cambridge: Routled. Grabois, H. (1999). The convergence of sociocultural theory and cognitive linguistics. Lexical semantics and the L2 acquisition of love, fear, and happiness. In Palmer, G.B. (Ed.), Language of sentiment. (pp. 201-233). Philadelphia, PA: John Benjamins Publishing Company, Retrieved 12 January, 2017 from http:// site.ebrary.com/lib/bham/Doc?id=5000285\&pp=207 https://doi.org/10.1075/ aicr.18.11 gra

Henriksen, B. (1999). Three dimensions of vocabulary development. Studies in Second Language Acquisition, 21, 303-17. https://doi.org/10.1017/S0272263199002089

Khazaeenezhad, B., \& Alibabaee, A. (2013). Investigating the role of language proficiency in word association behavior of L2 learners: a case of Iranian EFL learners. Theory and Practice in Language Studies, 3(1), 108-115. https://doi. org/10.4304/tpls.3.1.108-115

Kiss, G.R., Armstrong, C., Milroy, R., \& Piper, J. (1973). An associative thesaurus of English and its computer analysis. In Aitken, A.J., Bailey, R.W., HamiltonSmith, N. (Eds.), The Computer and Literary Studies. University Press, Edinburgh.

McCarthy, M. (1990). Vocabulary. Oxford: Oxford University Press.

Meara, P. (1982). Word associations in a foreign language: A report on the Birkbeck vocabulary project. Nottingham Linguistic Circular, 11(2), 29-31.

Meara, P. (1983). Word association in a foreign language. Nottingham Linguistics circular, 11(2), 29-38.

Peppard, J. (2007). Exploring the relationship between word-association and learners' lexical development. Retrieved 29 January, 2017 from http://www.bhamlive1. bham.ac.uk/Documents/college artslaw/cels/essays/lexis/PeppardMod2.pdf

Piper, T.H., \& Leicester, P.F. (1980). Word association behavior as an indicator of English language proficiency. University of British Columbia, Vancouver, B.C. 
Спроби аналізу ментального лексикону носїв та не носіїв мови...

Russ, R. (2010). Word association. Retrieved 15 January, 2017 from http://www. kansaiu.ac.jp/fl/publication/pdf_forum/9/3_robin.pdf

Soderman, T. (1993). Word associations of foreign language learners and native speakers: The phenomenon of a shift in response type and its relevance for lexical development. In H. Ringbom (Ed.), Near-native proficiency in English. (pp. 91-182). Abo, Finland: Abo Akademi.

Stevens, A. (1994). Jung: A very short introduction. Oxford: Oxford University Press.

Swan, M. (1997). The influence of the mother tongue on second language vocabulary acquisition and use. In Schmitt \& McCarthy. (pp. 156-180).

Wilks, C., \& Meara, P. (2002). Untangling word webs: Graph theory and the notion of density in second language word association networks. Second Language Research, 18(4), 303-324. https://doi.org/10.1191/0267658302sr203oa

Wolter, B. (2001). A depth of individual word knowledge model. Studies in Second Language Acquisition, 23, 41-69. https://doi.org/10.1017/S0272263101001024

Wolter, B. (2002). Assessing proficiency through word associations: is there still hope? System, 30, 315-329. https://doi.org/10.1016/S0346-251X(02)00017-9

\section{АНОТАЦІЯ}

У запропонованій статті порівнюється структура ментального лексикону англійської мови британських носіїв мови та іранців, які вивчають англійську мову як іноземну. Увага приділялась тому, як слова вибираються та використовуються двома групами досліджуваних - носіїв та не носіїв мови. Були проаналізовані типи поєднань словникових асочіацій, синтагматичні та парадигматичні зв'язки, які частіше використовуються двома групами. В експерименті взяли участь 40 англомовних носіїв та 40 не носіїв мови студентів чоловічої та жіночої статі. Порівнювався їхній ментальний лексикон. Відповідно до Оксрордського тесту визначення рівня володіння англійською мовою (ОРТ) немовні суб'єкти були розподілені на три групи рівнями сформованості вмінь: високий, середній та низький. Далі було запропоновано асоціативний словниковий тест (WAT) як носіям, так $і$ не носіям мови. Порівняння результатів тесту (WAT) за допомогою серії тестів Хи-квадрату та тесту Мана-Уітні дало змогу встановити, що зв'язки між словами варіюються між носіями та не носіями мови. Результати показали, що не носії мови, які утворювали більшість іранських студентів і вивчали англійську як іноземну, більшою мірою використовували синтагматичні зв'язки. Проте, лише один із учасників, який вивчав мову, використовував у висловлюваннях парадигматичні зв'язки, як і носії мови. Таким чином, був зроблений висновок про те, що студенти, які володіють мовою на високому рівні, використовують у висловлюваннях ті ж самі ментальні зв'язки, що і носії мови. Це дає змогу запропонувати заходи з покращення професійного рівня володіння мовою, що призводить до зміни ментальних зв'язків та зможе внести корективи щодо психологічної проблеми навчання мови та ії вивчення у більш академічному контексті та на вищому рівні.

Ключові слова: ментальний лексикон, слово-асоціація, парадигматичні зв'язки, синтагматичні зв'язки, ментальні зв'язки. 
Маржан Афруз, Багери Садег Мохамед, Задиги Фироз, Расеи Эзан. Попытки анализа ментального лексикона носителей и не носителей языка: случай ассоциативного сравнения слова

\begin{abstract}
АНнОТАЦИЯ
В статье сравнивается структура ментального лексикона английского языка британских носителей языка и иранцев, изучающих английский как иностранный. Внимание уделялось тому, как выбираются и используются слова этими двумя группами респондентов. Были проанализированы типы сочетаний словарных ассоциаций, синтагматические и парадигматические связи, чаще используемые двумя группами. Выводы: 40 англоязычных и 40 не носителей языка - студентов мужского и женского пола, приняли участие в эксперименте, посвященного сравнению их ментального лексикона. Согласно Оксфордскому тесту определения уровня владения английским языком (ОРТ) не носители английского языка были распределены по группам в зависимости от уровня сформированности речевых умений: высокий, средний и низкий. Далее был для выполнения был предложен ассоциативный словарный тест (WAT) как носителям, так и не носителям языка. Сравнение результатов теста (WAT) с помощью серии тестов Хи-квадрат и теста Мана-Уитни позволило установить, что связи между словами варьируются у носителей и не носителей языка. Результаты показали, что не носители языка, которыми были большинство иранских студентов, изучающих английский язык как иностранный, в большей степени использовали синтагматические связи. Однако, только один из участников, изучавший язык, использовал в речи парадигматические связи, как и носители языка. Таким образом мы пришли к выводам, что студенты, владеющие языком на высоком уровне, используют в речи те же ментальные связи, что и носители языка. Такие факты позволяют предпринять меры по улучшению профессионального уровня владения языком, что приводит к изменению ментальных связей и сможет внести коррективы в психологическую проблему обучения языку и его изучения в более академическом контексте и на высшем уровне.
\end{abstract}

Ключевые слова: ментальный лексикон, слово-ассоциация, парадигматические связи, синтагматические связи, ментальные связи. 